\title{
GEOLOGICAL, PETROLOGICAL AND TECTONIC FEATURES CHARACTERIZING THE COMMERCIALITY OF THE MARBLES OF SOUTHERN VERMION MOUNTAIN
}

\author{
Ploumis P. and Chatzipanagis I. \\ Institute of Geology and Mineral Exploration (IGME), Fragon 1, 54626 -Thessaloniki, \\ ploumis@thes.igme.gr,ixatzipanagis@gmail.com
}

\begin{abstract}
The southern Vermion mountain is composed of Pelagonian metamorphic rocks. Two different lithologic units are distinguished in this area. The first one consists of the highly metamorphosed rocks of Paleozoic age (migmatites, gneisses with marble intercalations and anatectic granites). The second unit comprises two series: the lower with schists, gneisses and marbles (200 m thick) and the upper with marbles (more than 2500 m thick). The age of the rocks in the second unit is TriassicJurassic and these are metamorphosed in greenshist facies.

During the last 40 years, the marbles of the second unit are being exploited for ornamental purposes in more than 100 quarries.Variations in chemical and mineralogical composition, grain size as well as some structural characteristics result to the 5 marble qualities - commercial types of Vermion mountain: a) White marbles, b) "Rigota" marbles, c) "Pitsilota" marbles, d) "Louloudata" marbles, e) Sipoline marbles.
\end{abstract}

Key words: White marbles, Pitsilota marbles, Rigota marbles, Louloudata marbles, Cipoline marbles, Pelagonian zone, south Vermion mountain, Central-North Greece.

\section{Introduction}

The studied area is located in the south Vermion mountain, between Aliakmon river, Polymylos, Tetralofos, Koumaria and Eripia Tormanis villages (Fig. 1). The bigger part of the studied area is occupied by marbles, some of which are exploited since the mid '60. More than 100 quarries are open in five areas. These areas are: Koumaria (15 quarries), Eripia Tormanis (16 quarries), Kastania (15

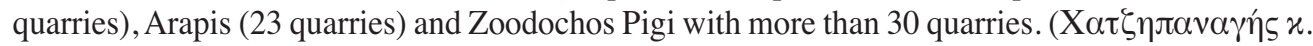
$\alpha ., 2009)$. Today only 6 of them are active. The exploitation has been considerably restricted because of various problems that appear to the marbles such as their colour, the tectonic strain, the ability of their polishing etc. In the south Vermion region, $1,4 \times 10^{6} \mathrm{~m}^{3}$ of marbles have been quarried and about $50.000 \mathrm{~m}^{3}$ of them have been exploited (X $\left.\alpha \tau \xi \eta \pi \alpha v \alpha \gamma \eta \dot{\eta}, 2009 \beta\right)$. This work identifies the commercial types of the south Vermion marbles according geological, mineralogical, petrological, structural - textural, chemical and aesthetic (colour, impourities) criteria. 


\section{Geological setting}

\section{1 Geology - lithostratigraphy}

The south Vermion mountain region is mainly composed of pelagonian metamorphic rocks which are partly covered by almopic nappes (Fig. 1). The pelagonian rocks are composed of two units of metamorphic rocks. The first, of Paleozoic age, is characterized of middle to high grade metamorphism. It is composed by schists, gneisses, augen gneisses, migmatized gneisses and thin bangs of marbles. Granite bodies of anatectic character, mainly related with the migmatites are exposed in some areas. This unit of thickness $>2000 \mathrm{~m}$ (Fig. 2) defines the basement of Pelagonian zone.

The second, younger unit, is of Triassic - Jurassic age (Mercier, 1968). It is composed primerily of marbles and gneisses and schists of middle - low grade metamorphism (greenshist facies). This unit is named the Eastern Carbonate Cover of Pelagonic zone (Kilias \& Moundrakis, 1989). Its basis of about $100 \mathrm{~m}$ thickness is composed of alternating suite of metaquarzites, schists ( \pm garnet) and albite gneisses. On this basis lie a series of white calcitic marbles (lower marbles series), called as the

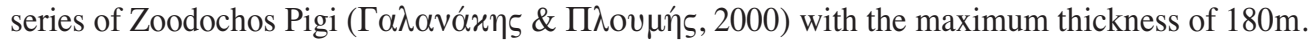
A series of gneisses of $\sim 200 \mathrm{~m}$ follow these marbles (Fig. 2).

A thick carbonatic series (upper marbles series) called as the series of Angkathi-Tsekouri

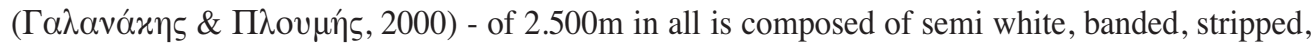
grey banded, and cipoline marbles, with intercalations of white marble bangs (X $\alpha \tau \zeta \eta \pi \alpha v \alpha \gamma \eta \dot{\eta}$, $2009 \alpha)$.

The Transgressive Carbonate Cover (Kilias \& Moundrakis, 1989) and the flysh, are found to be overthrusted on the metamorphic rocks of the Pelagonian zone in all their outcrops - always connected with ophiolites (X $\alpha \tau \zeta \eta \pi \alpha v \alpha \gamma \eta \dot{\zeta}, 2009 \alpha)$.

\section{2 Structural observations in marbles}

More or less, related with respectively metamorphic episodes, 4 or 5 deformation events are deter-

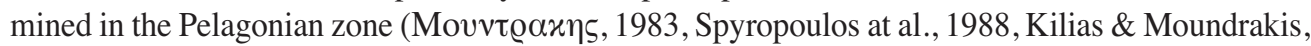
1987). Beyond the first deformation event of Paleozoic age which take place only in the basement rocks, all other episodes affect both units creating isoclinal folds, mylonitic zones, faults and overthrusts. The eastern Pelagonian part of the carbonatic cover is thrusted on the crystalline basement through a series of thrusts. Field observations in the frame of this work as well as the detailed stud-

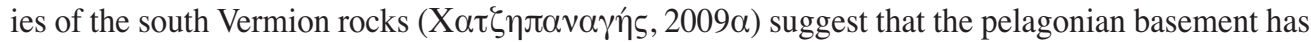
been affected by plastic deformation episodes, such as isoclinal folds, open folds, mylonites as well as by brittle deformation episodes such as shear zones and cataclastites while the carbonatic cover has been affected only by plastic deformation. Such brittle deformation evidences affect substantially the coherence and the aesthetic (texture, colour) of the marbles.

\section{Methods}

According to the chemical - mineralogical composition, the colour and even some tectonic deformation features, 5 commercial types of marbles are distinguished:

\subsection{White marbles}

They occupy the lower series of marbles (Zoodochos Pigi) as a single bang of a maximum thickness of $180 \mathrm{~m}$, between schists in Arapi and Zoodocho Pigi regions and as bangs of 10 to $15 \mathrm{~m}$ thickness 


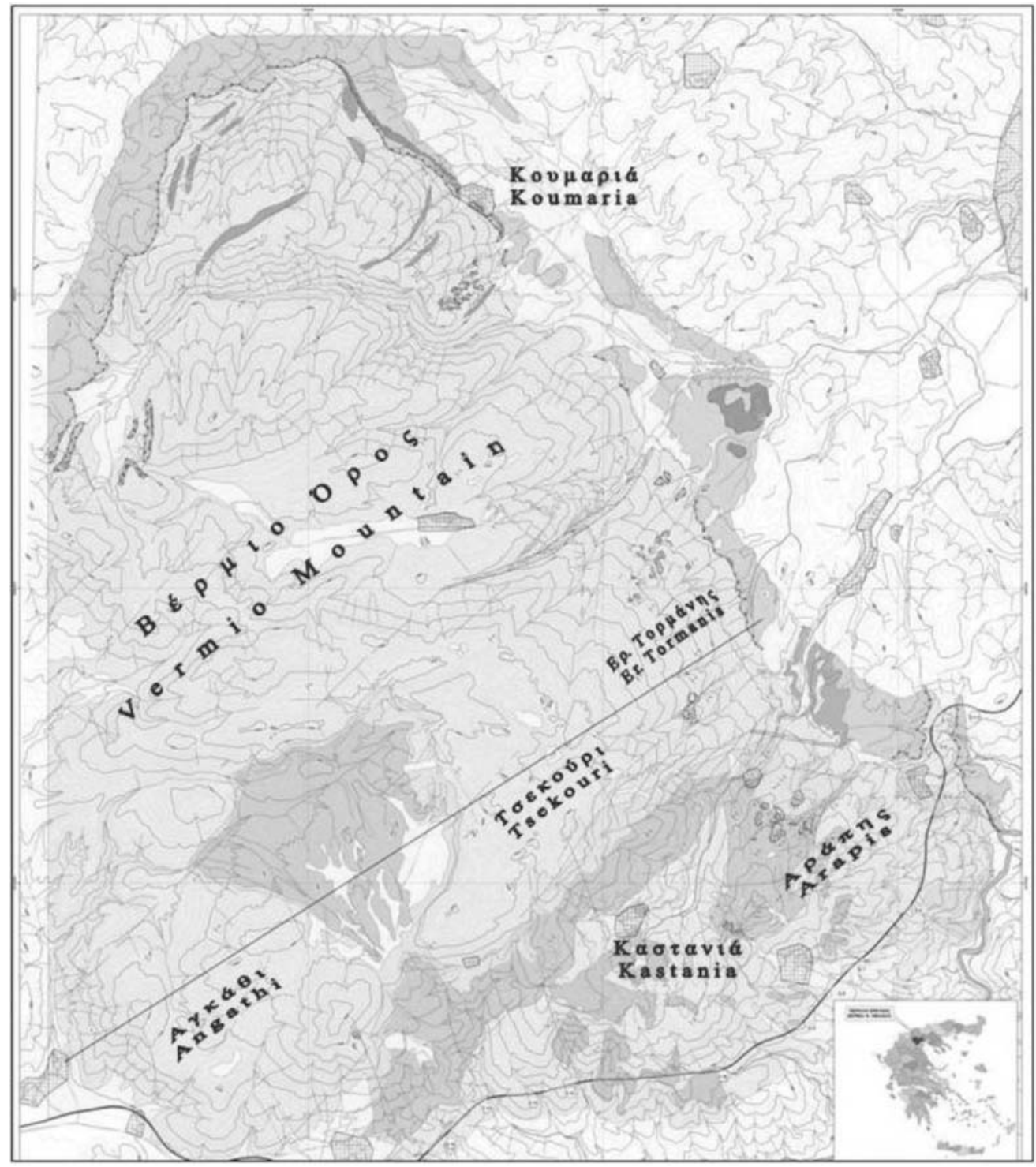

Fig. 1: Geological map of south Vermion mountain. 


\section{LEGEND}

Discared materials

Quaternary deposits

\section{ALMOPIAN NAPPES}

Conglomerates

Limstones, schists, phyllites

Ophiolites

\section{CARBONATE COVER OF PELAGONIAN ZONE}

Upper series of $m$ arbles

Schists

Interm ediate schists

Lower series of $m$ arbles

Schists, gneisses, metaquarzites

PALAEOZOIC BASAMENT OF PELAGONIAN ZONE

$\square$ Gneisses +/- migmatized, migmatites

Lenses of $m$ arbles

Granites

Faults whith tectonic breccias

..... Thrusting

Norm al faults

30 Strike and dip of foliation

(7) Quarries

Cross section $\mathbf{I}-\mathbf{I}^{\prime}$

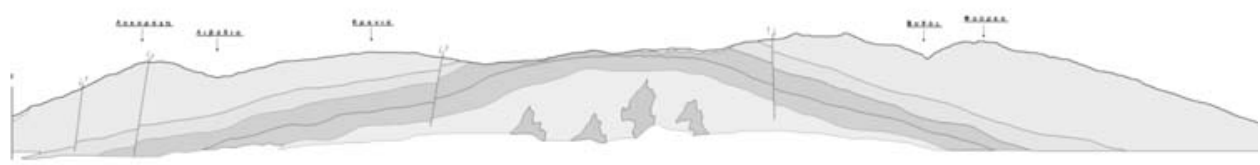




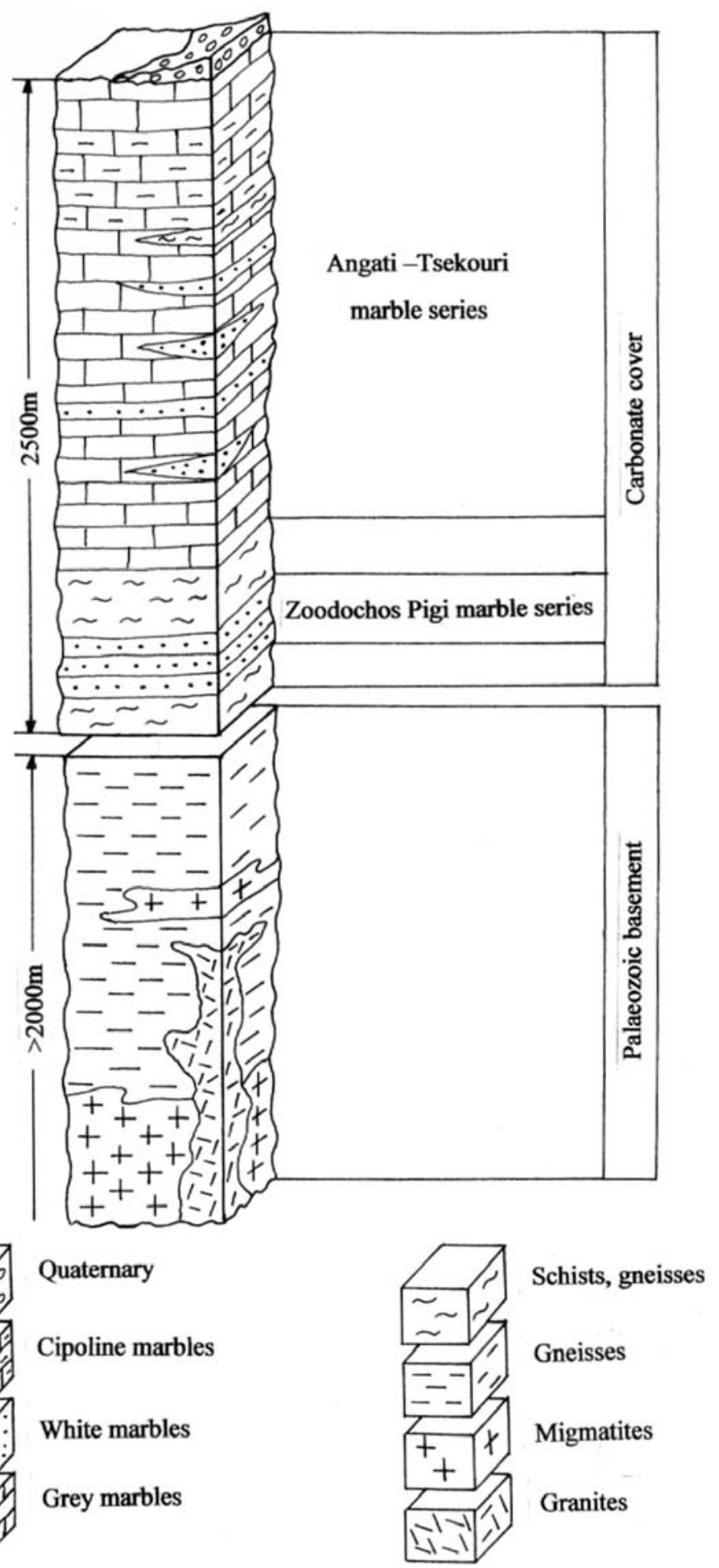

Fig. 2: Lithostratigraphic column of south Vermion mountain 
in the semi grey to grey, calcitic marbles of the upper series of marbles (Angathi-Tsekouri) in the Kastania, Eripia Tormanis and Koumaria reagions (Fig. 3).

At least 7 of those bangs of about 2.000m length have been mapped in the Koumaria region, 5 in

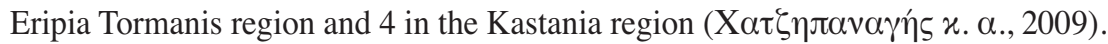

The white marbles of the upper series are characterized by the equigranular granoblastic texture

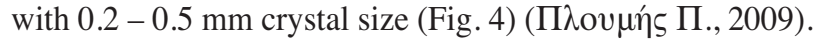

In the lower series, the marbles are characterized by their inequigranular texture and deformation features.

The initial crystals are broken in their periphery to smaller, creating two different crystal sizes ( 0.5 -0.8 and $0.1-0.3 \mathrm{~mm}$ respectively) (Fig. 5). Bended and broken calcite lamellas of the initial crystals are often observed.

These marbles are pure calcitic and only in some locations, Fe-oxides/hydroxides impregnations are observed.

\subsection{Pitsilota (flaked) marbles}

Pitsilota marbles are mainly located in Koumaria and Eripia Tormanis areas.

It is the case of white to semi white calcitic marbles with grey to black elongated flecks which are

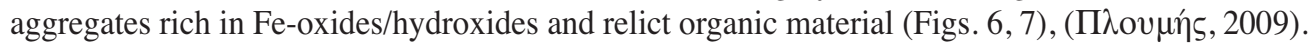

Usually, these flecks are discintiguous and spread but in some cases flecks of $15-20 \mathrm{~cm}$ in length and $1-2 \mathrm{~mm}$ thick are even observed. According to the mineralogical study of these flecks, beyond calcite, elongate aggregates of fine grain dolomite, relict organic material (amorphous - cryptokrystalline graphite), pyrite, Fe-oxides/hydroxides, mica, quartz, albite, zircon, routile and apatite, have been identified.

\subsection{Rigota (stripped) marbles}

Rigota marbles are mainly located in Kastania and Eripia Tormanis regions. They are semi white, semi grey to grey calcitic marbles with contiguous white stripes of $0.5-3 \mathrm{~mm}$ in thickness. (Figs . $8,9)$. These white stripes consist of fine grained $(0.2-0.4 \mathrm{~mm})$ calcite with $0.6-0.7 \% \mathrm{MgO}$. Along the cores of some stripes occur ultra fine grained $(0.05-0.1 \mathrm{~mm})$ dolomite aggregates (Fig. 10),

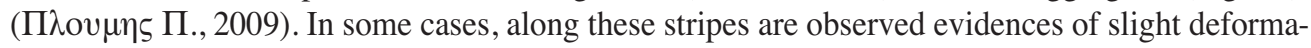
tion of the crystals.

In addition, in frame of late brittle tectonic, thin $(1-3 \mathrm{~mm})$ shear zones are detected. Along them, the calcite crystals are ultra fine grained (Figs. 11,12). Along these zones with the ultra fine grained material, some vestigial calcite crystals of the initial size with strongly bended lamellas can be seen (Fig. 13). The macroscopic evidence of the shear zones is also a white stripe cross cutting the older, contiguous white stripes (Fig. 11).

\subsection{Loulooudata (flowered) marbles}

They are located in the lower marble series, called as the Zoodochos Pigi series in the region of Arapi. The main mass (matrix) is a white to semi white marble with inequigranular granoblastic texture. Spread, separated, grey, big, idiomorphic monocrystals of calcite (Fig. 14) or aggregates of 


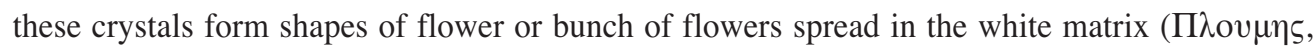
2009), (Fig. 15).Tthis commercial type of marble is named after thiw secondary creation "louloudata" (flowerd).

There have been found calcite monocrystals bigger than $5 \mathrm{~cm}$ (Fig. 16) and even bigger, alongate calcite aggregates. The aggregates consist either from elongate crystals in waved order (Fig. 17) or from crystals with uneven contacts (sutured texture). All these crystals of the "flowers" are secondary formation of calcite which fill cavities due to the dilution of the carbonates. Previous and late formations of dolomite and calcite have also been detected. (Fig. 17).

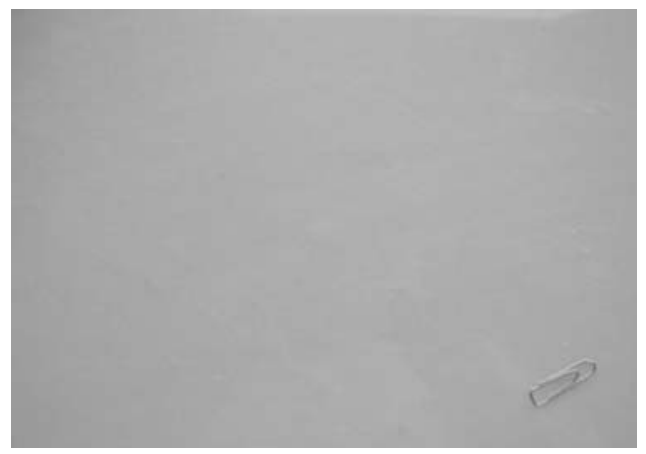

Fig. 3: White marble of Arapi area.

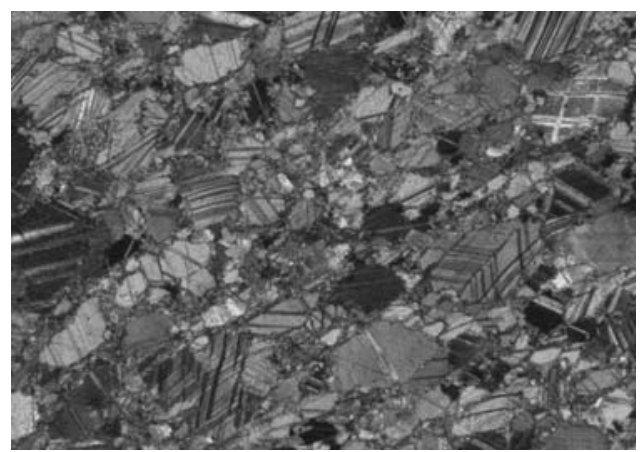

Fig. 5: Inequigranular marble of Zoodochos Pigi series $(+\mathrm{Nic}, \mathrm{x} 2.5)$

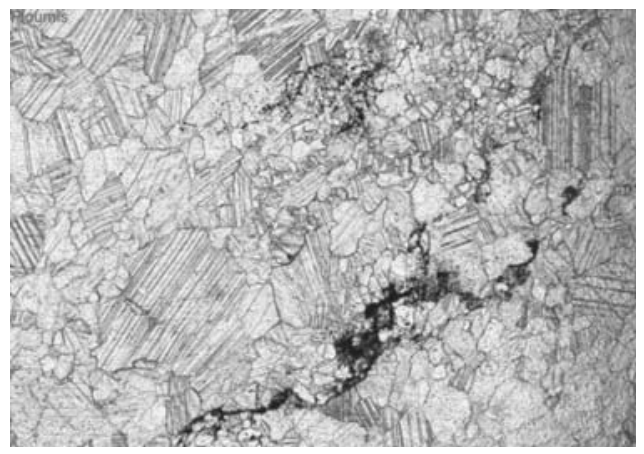

Fig. 7: Pitsila (fleck) in pitsilota marble of Koumaria area (//Nic., x5)

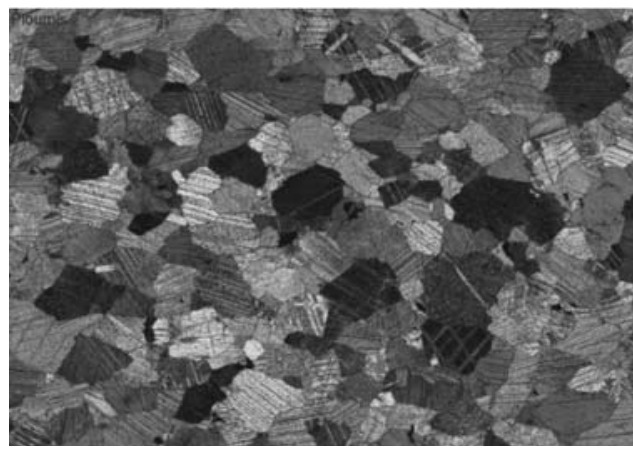

Fig. 4: Equigranular marble of Agathi - Tsekouri series $(+\mathrm{Nic}, \mathrm{x} 2.5)$.

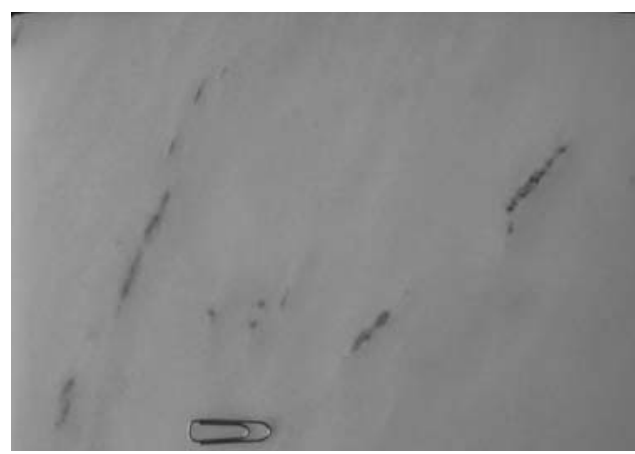

Fig. 6: Pitsilota marble of Koumaria area

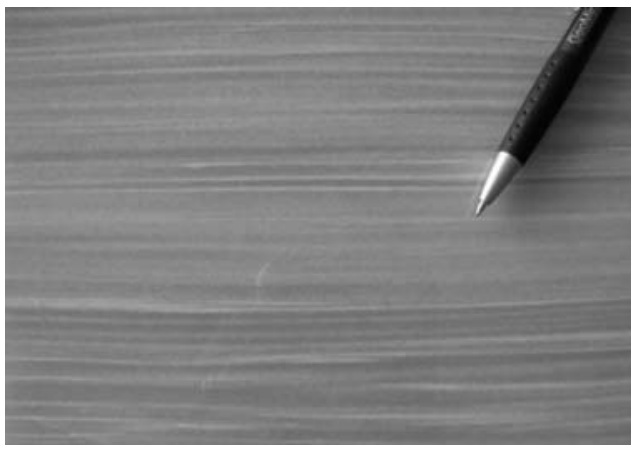

Fig. 8: Rigota marble of Er. Tormanis 


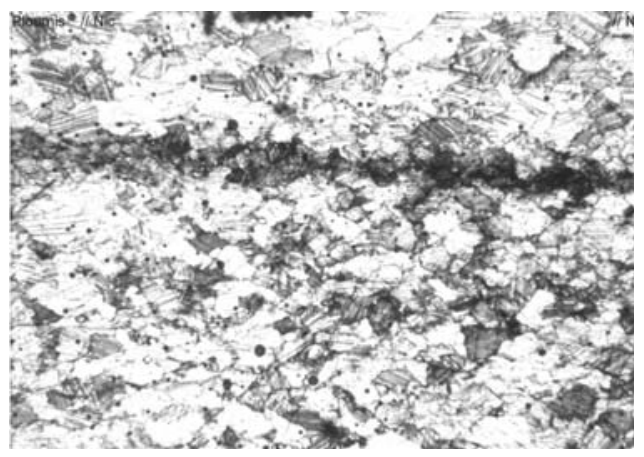

Fig. 9: The white stripe (dark in microscope image) of Koumaria area (//Nic., x1.25).

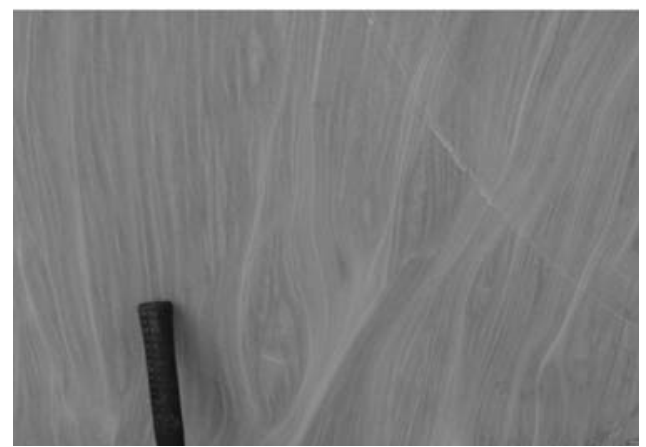

Fig. 11: Sheared Rigota marble of Er. Tormanis.

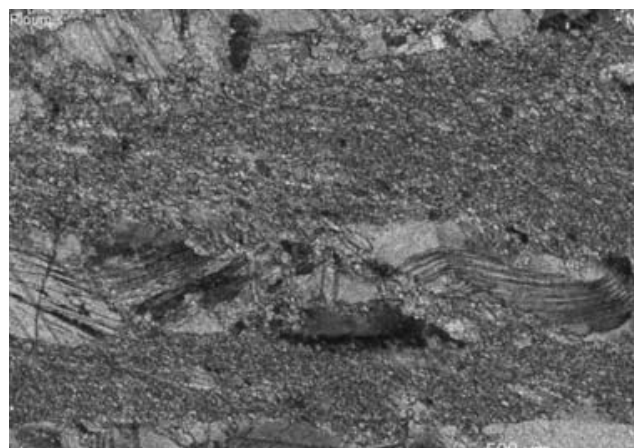

Fig 13: Initial size calcite crystals with bended lamellas in shear zone (detail of Fig. 12) (//Nic., x10).

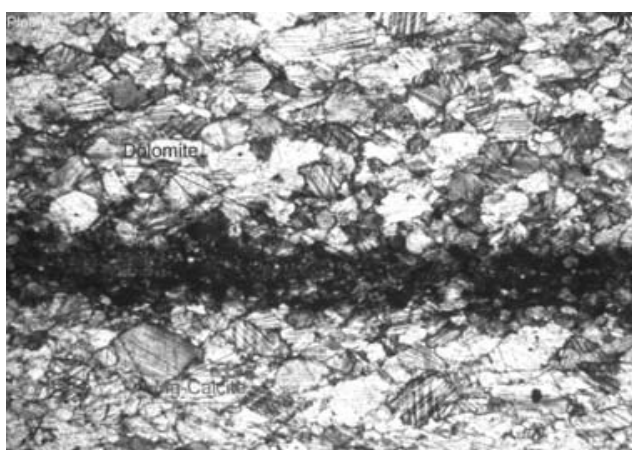

Fig. 10: White stripe with ultra fine dolomite in the core of the stripe (//Nic., x1.25).

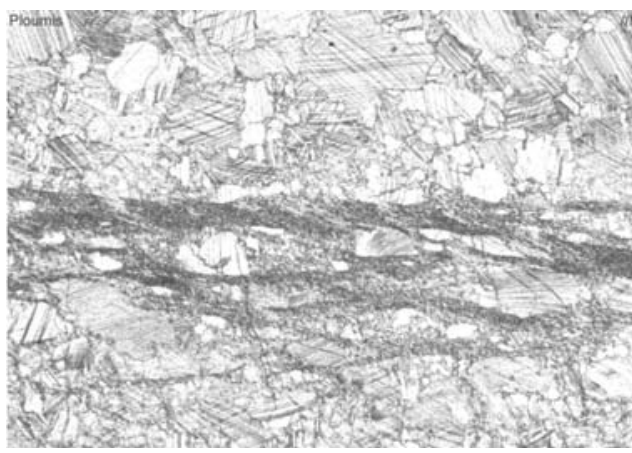

Fig. 12: Microscopic image of white stripe caused of shear (//Nic., x2.5).

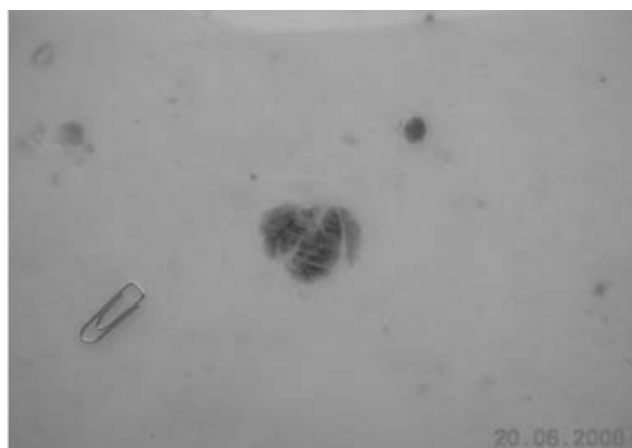

Fig 14: Calite monocrystal in louloudata marble of Arapi area. 


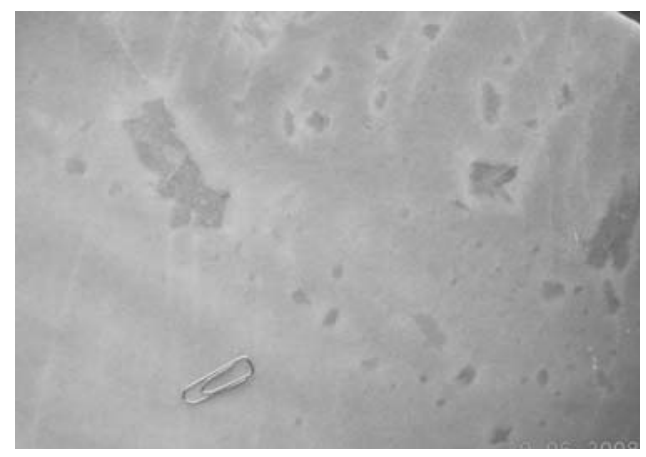

Fig. 15: Louloudata marble of Arapi area.

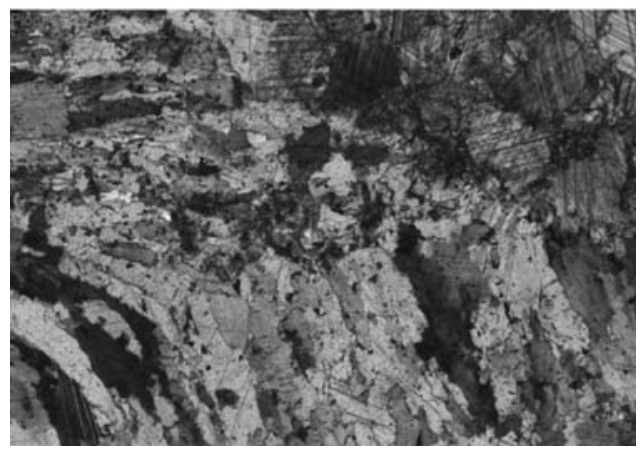

Fig. 17: Elongate calcite crystals in waved order $(+\mathrm{Nic}, \mathrm{x} 2.5)$.

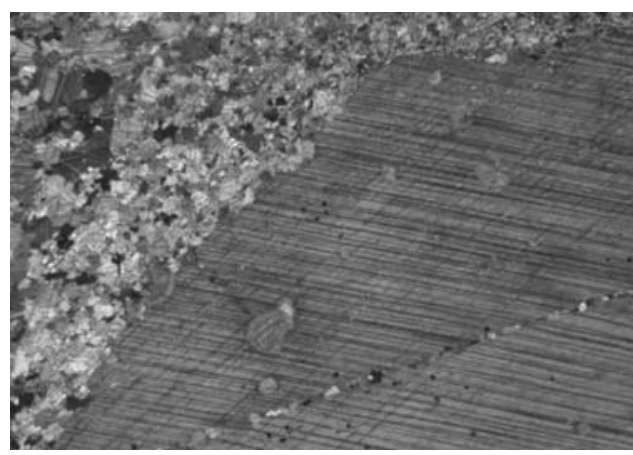

Fig. 16: Calcite monocrystal (+Nic,, $\mathrm{x} 1.25)$.

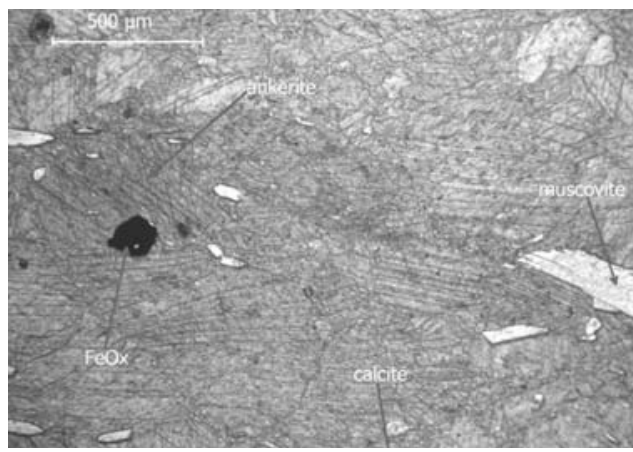

Fig. 18: Ankeritisation of calcite in the pyrite vicinity of of Koumaria area cipoline marble.

\section{5. Cipoline marbles}

Thin bangs of cipoline marbles occur in the region of Koumaria. Their maximum thickness is $400 \mathrm{~m}$.

They are semi grey to grey, fine to middle grain equigranular and inequigranular calcitic marbles. Long mica crystals $(\sim 5 \%)$, quartz, albite, pyrite, dolomite (in amounts in some locations), rutile, Fe

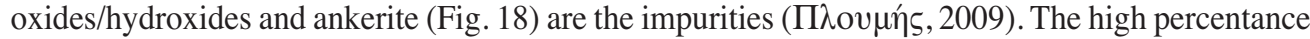
of mica in this marble creates serious problems to the face and shine of the plates.

\section{Conclusions -Results}

According to geological, mineralogical, petrological, structural - textural, chemical and aesthetic (colour, impourities) criteria, five (5) commercial marble types are being exploited in the south Vermion mountain:

- The pure calcitic $(99.5 \%)$ white marbles with inequigranular texture in the lower marble series, called as the series of Zoodochos Pigi and inequigranular in the upper series, called as the series of Angathi -TsekouriA. Some impurities of metallic oxides/hydroxides are localized in the bottom and top of the lower marble series and locally in the upper marble series.

- The calcitic, white to semi white pitsilota marbles of Angathi -Tsekouri series with grey to black elongated flecks which are aggregates rich in Fe-oxides/hydroxides and relict organic material. 
- The calcitic, semi white, semi grey to grey rigota marbles with contiguous white stripes of 0.5 $3 \mathrm{~mm}$ thickness. These white stripes consist of fine grained $(0.2-0.4 \mathrm{~mm})$ calcite with $0.6-0.7 \%$ $\mathrm{MgO}$. Wavy cross cutting white stripes of $1-3 \mathrm{~mm}$ thickness are shear zones, creating undulation forms to the striped marble. They occur in the Agathi - Tsekouri series.

- The, calcitic louloudata marbles with white to semi white, inequigranular granoblastic clcitic matrix texture with spread, separated, secondary grey, big, idiomorphic, calcite monocrystals or aggregates of these filling cavities after delusion of primary carbonates. This secondary creation forming shapes of flower or bunch of flowers gives the name to this commercial type of marble "louloudata" (flowerd) They occur in the lower marbles series (Zoodochos Pigi series).

- The semi white, semi grey to grey, calcitic cipoline marbles of the Zoodochos Pigi series with impurities of more than $5 \%$.

\section{Note}

This work is part of ongoing phd of Ploumis Panayiotis.

\section{References}

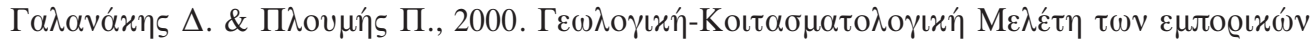

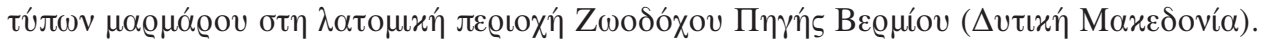

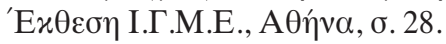

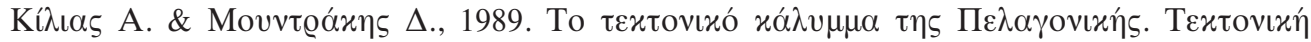

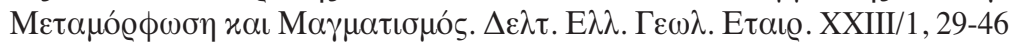

Kilias A. \& Mountrakis D. 1987. Zum tektonishen Bau der Zentral Pelagonishen Zone (Kamvounia Gebirge, N. Griechenland). Z. dt. Geol. Ges., 138, 211-237.

Mercier J., 1968. Étude géologique des zones internes des Hellénides en Macédoine central (Gréce). Contribution á l' etude du metamorphisme et de l' evolution magmatique des zones internes des Hellénides. Théses, Paris, 1966, Ann. Geol. Pays Hellen., 20, 1-792.

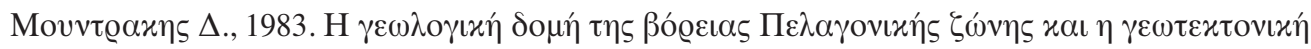

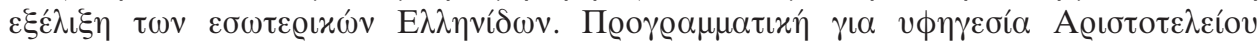

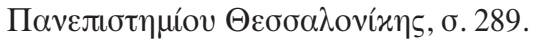

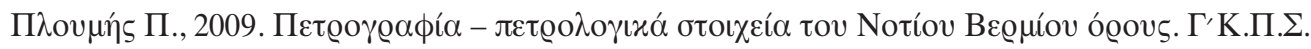

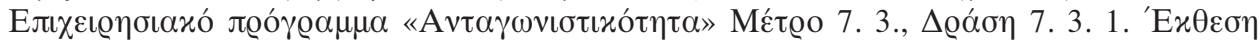

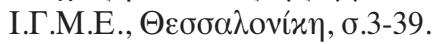

Spyropoulos N., Kilias A., Moundrakis D., 1988. Contribution to the study of the Structural Geology of the Pelagonian Zone in the Askion Mountains, W. Macedonia. Bull. Geol. Soc. Greece, Athens, xx, 121-138.

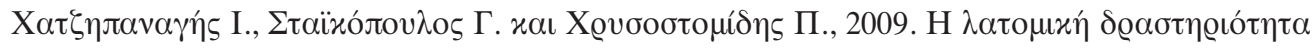

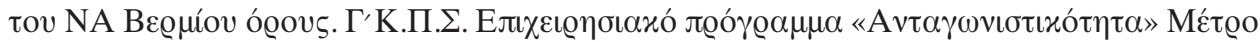

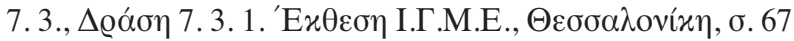

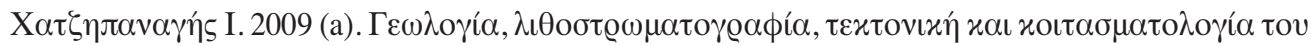

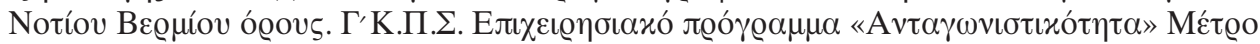

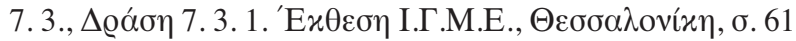

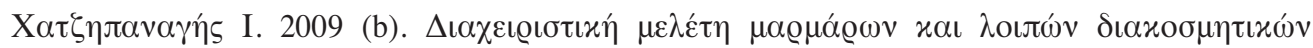

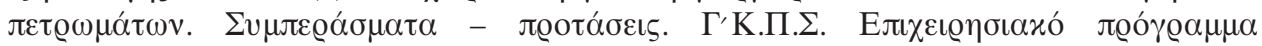

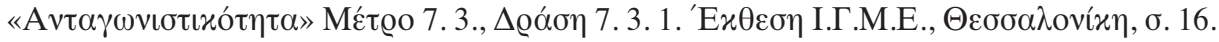

